\title{
Biointensive integrated management of Lipaphis erysimi Kalt. (Homoptera: Aphididae) in Brassica spp.
}

\author{
Deepak Sharma, Satyapal Yadav ${ }^{1}$ and Sunita Yadav* \\ Department of Entomology, CCS Haryana Agricultural University, Hisar-125004 (Haryana), INDIA \\ ${ }^{1}$ Regional Research Station, CCS Haryana Agricultural University, Rohtak-124004 (Haryana), INDIA \\ *Corresponding author. E-mail: sunitayadav10@rediffmail.com
}

Received: January 13, 2017; Revised received: May 15, 2017; Accepted: October 2, 2017

\begin{abstract}
Field experiment was conducted at Regional Research station, Samargopalpur, Rohtak (Haryana) during Rabi season of the year 2015-2016 to evaluate bioefficacy of various treatments against mustard aphid, Lipaphiserysimi on Indian mustard. Treatments were : $\mathrm{T}_{1}-$ Verticillium lecanii @ $10^{8} \mathrm{CS} / \mathrm{ml}, \mathrm{T}_{2}-$ Beauveria bassiana @ $10^{8}$ $\mathrm{CS} / \mathrm{ml}, \mathrm{T}_{3}$ - Neem seed kernel extract @ 5\%, T 4 - Neem seed methanol extract @ 5\%, T 5 - V. lecanii @ $10^{8} \mathrm{CS} / \mathrm{ml}+$ Clipping of infested twigs, $\mathrm{T}_{6}-$ B. bassiana @ $10^{8} \mathrm{CS} / \mathrm{ml}+$ Clipping of infested twigs, $\mathrm{T}_{7}-\mathrm{NSKE} @ 5 \%+$ Clipping of infested twigs, $\mathrm{T}_{8}-$ V. lecanii @ $10^{8} \mathrm{CS} / \mathrm{ml}+\mathrm{NSKE} @ 5 \%, \mathrm{~T}_{9}-$ B. bassiana @ $10^{8} \mathrm{CS} / \mathrm{ml}+\mathrm{NSKE} @ 5 \%$, T $10-$ Dimethoate 30EC @ $250 \mathrm{ml} /$ acre. Dimethoate was found to be most effective in reducing the aphid population (95.03\%) followed by V. lecanii @ $10^{8} \mathrm{CS} / \mathrm{ml}+$ NSKE @ 5\% (88.52 \%), NSKE @ 5\% + Clipping of infested twigs (87.77 \%) and B. bassiana @ 10 $\mathrm{CS} / \mathrm{ml}+$ NSKE @5\% (86.91\%) after ten days of spray. The highest seed yield was recorded in treatment dimethoate 30EC (1702 kg/ha) followed by V.lecanii @ 108 CS/ml +NSKE @ 5\% (1635 kg/ha), NSKE @ 5\% + Clipping of infested twigs (1626 kg/ha) and B.bassiana @ 10 CS/ml + NSKE @ 5\% (1617 kg/ha). Dimethoate was found to be highly costeffective with highest cost benefit ratio (1:14.92) followed by NSKE @ 5\% + clipping ofinfested twigs (1:13.81) and NSKE @ 5\% (1:11.41).
\end{abstract}

Key words: Dimethoate, Lipaphis erysimi, Mustard aphid, NSKE, Seed yield

\section{INTRODUCTION}

Oilseed Brassicas, collectively known as rapeseedmustard comprise traditionally grown indigenous species, namely toria (Brassica rapa L. var. toria), brown sarson (Brassica rapa L. var. brown sarson), yellow sarson (Brassica rapa L. var. yellow sarson), Indian mustard (Brassica juncea), black mustard (Brassica nigra) and taramira (Eruca sativa), which have been grown since about 3,500 BC along with non -traditional species like gobhi sarson (Brassica napus) and Ethiopian mustard or karan rai (Brassica carinata). India is one of the largest rapeseed mustard growing countries in the world, occupying the first position in area and second position in production after China (Khavse et al., 2014). India accounts for $14.8 \%$ of rapeseed production at global level and occupies prime position in the World (Singh, 2014). Among the seven edible oilseeds (Groundnut, rapeseed mustard, soybean, sunflower, sesame, safflower and niger) cultivated in India, rapeseed-mustard contributes $28.6 \%$ in the total oilseeds production and ranks second after groundnut sharing $27.8 \%$ in the India's oilseed economy (Shekhawat et al., 2012). In India, during 2013-14, rapeseed and mustard were grown over an area of 6.70 million ha area with production and productivity of $7.96 \mathrm{~m}$ tonnes and $1188 \mathrm{~kg} / \mathrm{ha}$ respectively (Anonymous, 2015). Rajasthan, Uttar Pradesh, Madhya Pradesh, Haryana, Gujarat and West Bengal states accounted for nearly $86.5 \%$ area and $91.4 \%$ production of rapeseed-Mustard in the country during 2012-13 (Anonymous, 2015a). Among oilseed Brassica species, major area is under $B$. juncea which contributes about $80 \%$ of the total rapeseed-mustard production in the country. In Haryana, during 2013-14, rapeseed and mustard were grown on 0.54 million ha area with production and productivity of $0.88 \mathrm{~m}$ tonnes and $1639 \mathrm{~kg} / \mathrm{ha}$, respectively (Anonymous, 2015b).

The realization of full yield potential ofrapeseed mustard is prevented by various factors but main reason is thatthese energy rich crops are generally grown on marginal and sub marginal lands under rainfed conditions and are also severally affected by vagaries of biotic (weeds, diseases and insect-pests) and abiotic (drought, frost and salinity) stresses. Insect pests are important biotic constraints that posed severe threat to mustard from germination to harvest and about 50 insect species have been found infesting the rapeseedmustard in India (Sharma and Singh, 2010), out of which about a dozen of species are considered as major pest (Singh, 2009). Among them, the aphid species that damage rapeseed-mustard in India include 
Lipaphis erysimi, Brevicornae brassicae L. and Myzuspersicae Sulzer (Sarangdevot et al.,2006). Among these, L. erysimi referred as both the turnip and mustard aphid is one of the major limiting factors causing up to 96 percent yield losses (Sharma and Kashyap 1998; Singh and Sharma 2002 and Shylesha et al., 2006). Verma and Singh, 1987 recorded $15 \%$ reduction in oil content due to mustard aphid infestation. Aphid sucks the cell sap from the stems, twigs buds, flowers and developing pods causing a significant loss in yield. Kular and Kumar (2011) reported that the losses in seed yield ranged from 6.5 to 26.4 per cent of different Brassica species (B. juncea, B. napus, B. carinata, B. rapa and E. sativa) by the infestation of mustard aphid.

Control of aphids is a difficult task because of their rapid growth, mode of reproduction, polymorphic nature and ability to adopt different kinds of environment. A number of chemical insecticides have been found effective against this pest in different parts of the country (Singh and Verma, 2008; Singh and Singh, 2009). But the indiscriminate use of the insecticides has resulted into several problems like environmental pollution, health hazards to human beings, toxicity to pollinators \& natural enemies etc. (Singh, 2001). So it is necessary to find alternate economical and environmentally safe methods for pest control. The botanicals and bio-agents are more compatible with the environmental components, eco-friendly with plant health and nonhazardous to human being. Meena et al. (2013) evaluated microbial agents and bio-products for the management of mustard aphid and found that the per cent reduction of aphid population after 10 days of spray was maximum under dimethoate 30EC @ 300 g a.i/ha (91.00\%) followed by NSKE@5\%(83.20\%),B.bassiana@5 g per litre of water $(78.00 \%)$, cow urine @ 50 litre per ha $(76.33 \%)$, onion extract @ 5\% (76.00\%), tobacco extract@5\%(75.40\%),V.lecanii@5 g per litre of water $(75.0 \%)$ and $M$. anisopliae@ 5 g per litre of water $(74.0 \%)$. Keeping the above facts in mind the present investigation was undertaken to evaluate the eco-friendly bio-products.

\section{MATERIALS AND METHODS}

The present investigation was carried out during Rabi season of the year 2015-16 at Regional Reasearch Station, Samargopalpur, Rohtak (Haryana), India. Experiment was conducted in a completely randomized block design with ten treatments including control and replicated thrice with plot size of $4.2 \times 3 \mathrm{~m}$ on mustard cv. RH 0749. The crop was sown during first fortnight of November with row to row and plant to plant distance as $30 \mathrm{~cm}$ and $10 \mathrm{~cm}$ respectively and all the standard agronomic practices were followed to raise the good crop. Sowing was done $13^{\text {th }}$ November, 2015 i.e. under late sown conditions to ensure heavy aphid infestation. A fertilizer dose of $80 \mathrm{~kg} \mathrm{~N}, 30 \mathrm{~kg} \mathrm{P}_{2} \mathrm{O}_{5}$ and $20 \mathrm{~kg} \mathrm{~K} \mathrm{~K}_{2} \mathrm{O} / \mathrm{ha}$ was given to all the plots uniformly. Crop was irrigated once at the time of flowering. Eleven treatments including control were T1: Verticillium lecanii@10 $10^{8} \mathrm{CS} / \mathrm{ml}$ (Conidial Spore per millilitre), T2: Beauveria bassiana@10 10 CS/ml, T3: NSKE@5\%,T4: Neem Seed Methanol Extract@ 5\%, T5:V.lecanii@10 $10^{8} \mathrm{CS} / \mathrm{ml}+$ Clipping of infested twigs, T6: B. bassiana@10 $10^{8} \mathrm{CS} / \mathrm{ml}+$ Clipping of infested twigs, T7: NSKE@5\%+Clipping of infested twigs, T8:V.lecanii@108 CS/ml + NSKE@5\%, T9: B.bassiana@10 $10^{8} \mathrm{CS} / \mathrm{ml}+\mathrm{NSKE} @ 5 \%$, T10: Dimethoate 30EC@250 ml/acre and T11: Control with no spray. The population of aphids was counted from ten randomly selected plants from each plot one day before and 3, 7, and 10 days after spray of insecticides. The aphids were counted from the top 10 $\mathrm{cm}$ apical twigs of these selected plants with the help of a magnifying glass. The numbers of aphids/plant were converted into \% reduction of aphid population over the control. Yield was recorded from net plot area and converted in to kilogram per ha and data were statistically analyzed. The incremental cost benefit ratio was calculated by prevailing market price of mustard seed, cost of insecticides and labour used with the following formula.

Cost benefit ratio $=$ Additional profit over the control Cost of treatment.

\section{RESULTS AND DISCUSSION}

Before treatment, mean aphid population ranged from 19.62 to 25.90 aphids $/ 10 \mathrm{~cm}$ main apical shoot and found to be non-significant which indicates that the aphid population was uniformly distributed. Aphid population decreased in all treated plot at $3^{\text {rd }}$ day after spray, and ranged from 3.93 to 15.56 aphids $/ 10 \mathrm{~cm}$ main apical shoot as compared to control with the highest population of 27.07 aphids $/ 10 \mathrm{~cm}$ main apical shoot.The minimum aphid population (3.93 aphids/10 $\mathrm{cm}$ main apical shoot) was recorded in treatment $\mathrm{T}_{10}$ : Dimethoate $30 \mathrm{EC}$ and it was significantly superior over rest of the treatments. Similar results were obtained at $7^{\text {th }}$ and $10^{\text {th }}$ day after spray. The mean aphid population ranged from 3.11 to 12.60 aphids $/ 10 \mathrm{~cm}$ main apical shoot at $7^{\text {th }}$ day after spray and 1.97 to 9.80 aphids $/ 10 \mathrm{~cm}$ main apical shoot at $10^{\text {th }}$ day after spray.

The per cent aphid reduction over control after ten days of spray was found to be maximum $(95.03 \%)$ in treatment $\mathrm{T}_{10}$ : Dimethoate $30 \mathrm{EC}$ followed by $\mathrm{T}_{8}: V$. lecanii@10 $0{ }^{8} \mathrm{CS} / \mathrm{ml}+\mathrm{NSKE} @$.5\% (88.52\%), T NSKE@5\% + clipping of infested twigs (87.77\%), $\mathrm{T}_{9}$ : B. bassiana@10 $10^{8} \mathrm{CS} / \mathrm{ml}+\mathrm{NSKE@5 \% (86.91}$ \%), $\mathrm{T}_{5}$ : V.lecanii@10 $10^{8} \mathrm{CS} / \mathrm{ml}+$ clipping of infested twigs (86.71\%), $\mathrm{T}_{6}$ : B. bassiana@10 $10^{8} \mathrm{CS} / \mathrm{ml}+$ clipping of infested twigs $(84.09 \%)$ and $\mathrm{T}_{3}$ : NSKE@ $5 \%(82.63 \%)$. Minimum reduction in aphid population 
Deepak Sharma et al. / J. Appl. \& Nat. Sci. 9 (4): 2132 - 2136 (2017)

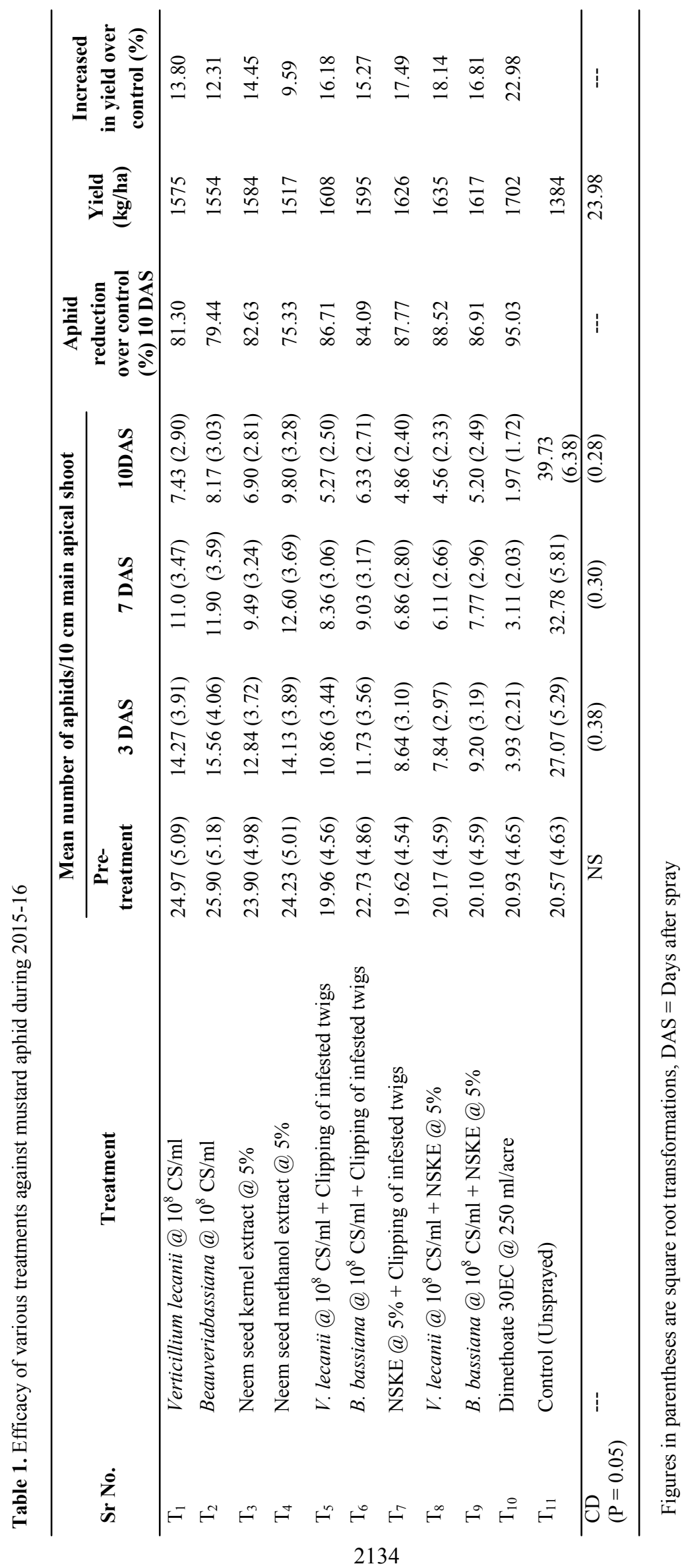


Deepak Sharma et al. / J. Appl. \& Nat. Sci. 9 (4): 2132 - 2136 (2017)

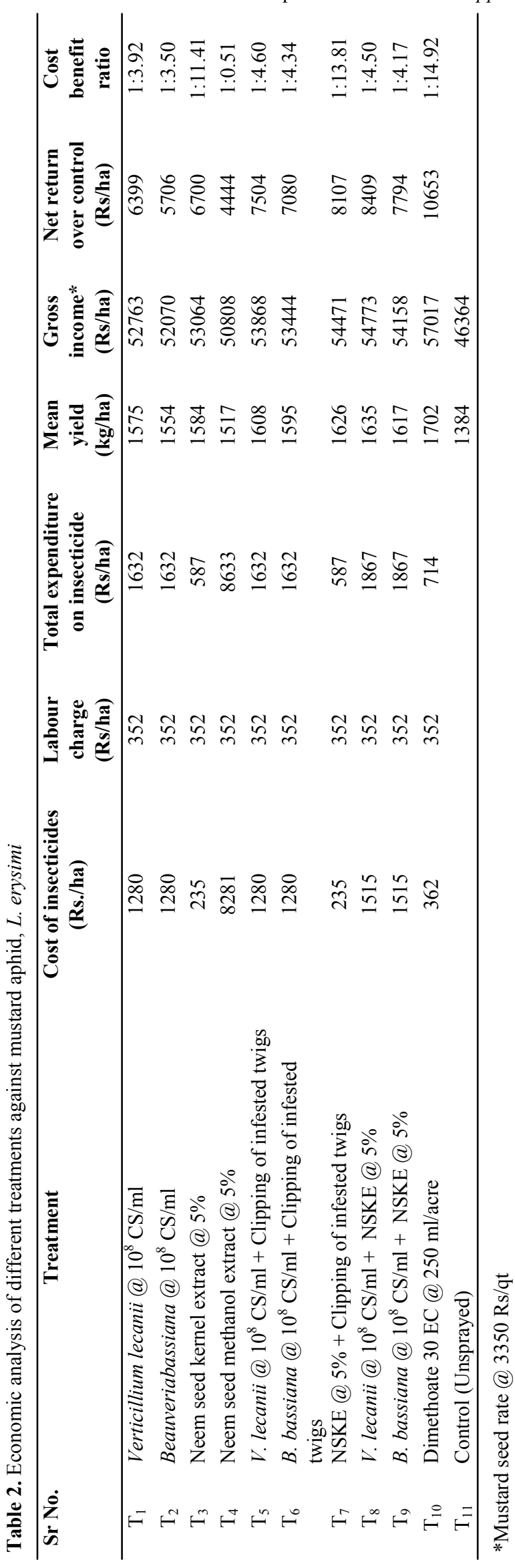

over control after ten days of spray was recorded in treatment $\mathrm{T}_{4}$ : neem seed methanol extract @ 5\% (75.33\%) followed by $\mathrm{T}_{2}$ : B. bassiana@10 $10^{8} \mathrm{CS} / \mathrm{ml}$ (79.44\%) and $\mathrm{T}_{1}$ : V. lecanii@10 $10^{8} \mathrm{CS} / \mathrm{ml}(81.30$ \%).Gour and Pareek(2003) and Konar and Paul (2005) also observed that dimethoate was the most effective insecticide against mustard aphid. The present studies are further supported by work of Singh et al. (2014) who found that dimethoate @ 300g a.i. ha ${ }^{-1}$ was effective against aphid population causing 91.1, 93.5 and 96.2 per cent reduction in aphid population after 3 , 7 and 10 days of spray respectively. Singh et al. (2008) while testing entomopathogenic fungi against the mustard aphid found that V. lecanii@ $10^{8}$ spores $/ \mathrm{ml}$ was effective in controlling the aphid population by 75.79 per cent. Singh (2007)reported 79.4 per cent reduction in aphid population after 10 days of application of NSKE@5\%. Singh and Lal (2011) reported that use of NSKE@ $@$ \% alone was effectivein reducing the mustard aphid population significantly while in combination with mechanical (hand removal) and botanical (NSKE) was found to be more effective. Nagar et al. (2012) revealed that dimethoate @ $300 \mathrm{~g}$ a.i/ha and NSKE@5\% reduced the aphid population by $90.87 \%$ and $84.48 \%$, respectively after 10 days of spray. Meena et al. (2013) found 91.0,83.2, 78.0 and 75.0 per cent reduction in aphid population after 10 days of spray of dimethoate 30EC@300 g a.i/ha, NSKE@5\%,B.bassiana@5g per litre of water and V.lecanii@5 gper litre of water, respectively (Table 1). Kumar (2011) reported that the pooled mean aphid population in the spray of $V$. lecanii @ $10^{8} \mathrm{CS} / \mathrm{ml}$ was $11.8,14.0$ and 17.0 aphids/plant as against $64.4,84.3$ and 73.8 aphids/plant in the control after 3,7 and 10 days of treatment.

Among the different treatments, the maximum seed yield of $1702 \mathrm{~kg} / \mathrm{ha}$ was recorded in treatment $\mathrm{T}_{10}$ : Dimethoate $30 \mathrm{EC}$ and it was found significantly superior over rest of the treatments. The next most effective treatment was $\mathrm{T}_{8}: V$. lecanii@10 $10^{8} \mathrm{CS} / \mathrm{ml}+\mathrm{NSKE} @$ $5 \%(1635 \mathrm{~kg} / \mathrm{ha})$ which remained on par with $\mathrm{T}_{7}$ : NSKE@5\% + clipping of infested twigs (1626 kg/ha) and $\mathrm{T}_{9}:$ B. bassiana@10 $10^{8} \mathrm{CS} / \mathrm{ml}+\mathrm{NSKE@5 \%}$ (1617 kg/ha). The treatment $\mathrm{T}_{5}:$ V. lecanii@10 $10^{8} \mathrm{CS} / \mathrm{ml}$ + clipping of infested twigs $(1608 \mathrm{~kg} / \mathrm{ha})$ and $\mathrm{T}_{6}: B$. bassiana@10 $\mathrm{CS} / \mathrm{ml}+$ clipping of infested twigs $(1595 \mathrm{~kg} / \mathrm{ha})$ were found on par with each other. The treatment T3: NSKE@5\% (1584 kg/ha)was found on par with treatment $\mathrm{T}_{1}$ :V. lecanii@108 CS/ml (1575 $\mathrm{kg} / \mathrm{ha})$. The least effective treatment was $\mathrm{T}_{4}$ : neem seed methanol extract@5\% (1517 kg/ha). The minimum seed yield $(1384 \mathrm{~kg} / \mathrm{ha})$ was recorded in untreated plot(Table 1).

The highest $\mathrm{C}: \mathrm{B}(1: 14.92)$ was obtained from treatment $\mathrm{T}_{10}$ : Dimethoate $30 \mathrm{EC}$ followed by $\mathrm{T}_{7}$ : NSKE@ @ $\%$ + clipping of infested twigs (1:13.81), T 3 : NSKE@ 5\%(1:11.41), $\mathrm{T}_{5}:$ V. lecanii @ 10 ${ }^{8} \mathrm{CS} / \mathrm{ml}+$ clipping of 
infested twigs (1:4.60), $\mathrm{T}_{6}:$ B. bassiana @ $10^{8} \mathrm{CS} / \mathrm{ml}+$ clipping of infested twigs $(1: 4.34)$ and $\mathrm{T}_{9}: B$. bassiana (a) $10^{8} \mathrm{CS} / \mathrm{ml}+\mathrm{NSKE}$ (a) 5\%) (1:4.17). The lowest C:B (1:0.51) was obtained from treatment $\mathrm{T}_{4}$ : Neem seed methanol extract @5\% followed by $\mathrm{T}_{2}$ : B. bassiana@10 CS/ml (1:3.50) and $\mathrm{T}_{1}$ : V. lecanii @ $10^{8} \mathrm{CS} / \mathrm{ml}$ (1:3.92). Meena et al. (2013) evaluated microbial agents and bio-products for the management of L. erysimi and found the most favourable c ost-benefit ratio under the treatment i.e. dimethoate 30 EC @ $300 \mathrm{~g}$ a.i/ha (1:38) followed by neem seed kernel extract @ 5\% (1:18) (Table 2).

\section{Conclusion}

From the present findings, it may be concluded that though dimethoate 30EC was most effective in managing mustard aphid but there is urgent need to adopt eco and user friendly pest control methods against mustard aphidto conserve the pollinators and natural enemies as well as to protect the human health. Among non-chemical methods, V. lecanii @10 $10^{8} \mathrm{CS} /$ ml+NSKE@5\% and NSKE@ @ + clipping of infested twigs may be recommended as most economic and effective treatments for the management of mustard aphid, L. erysimi on Indian mustard.

\section{REFERENCES}

Anonymous (2015). Directorate of Rapeseed-Mustard Research, Bharatpur, Rajasthan. www.drmr.res.in/ about_rm.html

Anonymous (2015a). Directorate of Rapeseed-Mustard Research, Bharatpur, Rajasthan.www.icar.org.in/Vision\% 202050\%20DRMR\%20Rajasthan.pdf

Anonymous (2015b). Agriculture statistics at a glance, 2014. Directorate of Economics and Statistics, Department of Agriculture and Cooperation, Ministry of Agriculture, Government of India. Published by Oxford University Press, New Delhi.1: 110-111.

Gour, I.S. and Pareek, B.L. (2003). Field evaluation of insecticides against mustard aphid, Lipaphiserysimi (Kalt.) under semi-arid region of Rajasthan. Indian Journal of Plant Protection, 31: 25-27.

Khavse, R., Singh, R., Manikandan, N. and Chaudhar, J.L. (2014). Influence of temperature on rapeseed-mustard yield at selected locations in Chhattisgarh state. Current World Environment, 9(3): 1034-1036.

Konar, A. and Paul, S.(2005). Comparative field efficacy of synthetic insecticides and biopesticides against aphid on potato. Annual of Plant Protection Science, 13: 34-36.

Kular, J.S. and Kumar, S. (2011). Quantification of avoidable yield losses in oilseed Brassica caused by insect-pests. Journal of Plant Protection Research, 51(1): 38-43.

Kumar, S. (2011). Evaluation of eco-friendly products against Lipaphiserysimi (Kaltenbach) infesting Indian mustard. Journal of Insect Science, 24:132-135.

Meena, H., Singh, S.P. and Nagar, R. (2013). Evaluation of microbial agents and bio-products for the management of mustard aphid, Lipaphiserysimi (Kalt.). The Bioscan, 8(3): 747-750.

Nagar, A., Singh, S.P., Singh, Y.P., Singh, R., Meena, H. and
Nagar, R. (2012). Bioefficacy of vegetable and organic oils, cakes and plant extracts against mustard aphid, Lipaphis erysimi (Kalt.). Indian Journal of Entomology, 74(2): 114-119.

Sarangdevot, S.S. Kumar, A. and Chundawat, G.S. (2006). Field bio-efficacy of some newer insecticides against aphids infesting tomato crop. Pestology, 30(3): 20-22.

Sharma, P. and Singh, Y.P. (2010). Directrate of Rapeseedmustard, Indian Council of Agriculture Research, Sewar, 321303, Bharatpur (Rajasthan). Annual National Language Journal, 1: 4751.

Sharma, P.K.,Kashyap, N.P. (1998). Estimation of losses in three different oil seed Brassica crops due to aphid complex in Himachal Pradesh (India). Journal of Entomological Research, 22: 22-25.

Shekhawat, K., Rathore, S.S., Premi, O.P., Kandpal, B.K. and Chauhan, J.S. (2012). Advances in agronomic management of Indian mustard (Brassica juncea (L.) Crenz. Cosson): An Overview. International Journal of Agronomy, 2012: 14.

Shylesha, A.N., Azad Thakur, N.S., Pathak, K.A., Rao, K.R., Saikia, K., Surose, S., Kodandaram, N.H. and Kalaishekar, A. (2006). Integrated management of insect pest of crops in north eastern hill region. Technical Bulletin No. 19. ICAR RC for NEH Region, Umiam, p. 50.

Singh, A.K. and Lal, M.N. (2011). Ecofriendly approaches for management of mustard aphid, Lipaphiserysimi. Annals of Plant Protection Sciences, 19: 93-96.

Singh, D. (2014). Genetic enhancement of mustard for seed yield and its sustainability. Paper presented in 2nd National Brassica Conference held at PAU Ludhiana from Feb. 14-16 (2014). p. 18.

Singh, D.K., Pal, S., Dwivedi, R.K. and Pal, R.K. (2014). Efficacy of insecticides against mustard aphid, $L i$ paphiserysimi (Kalt.). Annals of Plant Protection Science, 22(1): 39-41.

Singh, P.K. (2001). Control of mustard aphid, Lipaphis erysimi (Kalt.) (Homoptera: Aphididae) with minimum insecticide use. Journal of Aphidology. 15: 139-42.

Singh, R.K. and Verma, R.A. (2008). Relative efficacy of certain insecticides against mustard aphid (Lipaphis erysimi) on Indian mustard (Brassica juncea). Indian Journal of Agricultural Sciences. 78: 821-823.

Singh, S.P. (2009). Insect pest management in oilseed crops. Indian farming, 58(7): 29-33.

Singh, S.P. and Singh, Y.P. (2009). Bio-efficacy of pesticides against mustard aphid. Annals of Plant Protection Sciences, 17(1): 240-242.

Singh, Y.P. (2007). Efficacy of plant extracts against mustard aphid, Lipaphis erysimi (Kalt.) on mustard. Indian Journal of Plant Protection, 35(1): 116-117.

Singh, Y.P., Sharma, K.C. (2002). Integrated approach to manage the mustard aphid LipaphiserysimiK. (Homotera: Aphididae) in oil seed Brassica crops-a review. Journal of Amphibiology, 16: 77-88.

Singh, Y.P., Singh, S.P. and Meghwal, H.P. (2008). Evaluation of bioagents against mustard aphid, Lipaphis erysimi (Kalt.) (Homoptera: Aphididae) under net covered condition in field. Journal of Biological Control, 22: 321-326.

Verma, S.N., Singh, O.P. (1987). Estimation of avoidable losses to mustard by the aphid, Lipaphis erysimiin Madhya Pradesh. Indian Journal of Plant Protection, 15: 87-89. 